\title{
Structure of prodigiosin from Serratia marcescens NJZT-1 and its cytotoxicity on TSC2-null cells
}

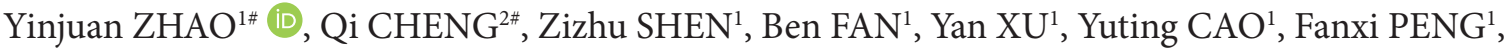 \\ Jingkai $\mathrm{ZHAO}^{1}$, Bin $\mathrm{XUE}^{2,3 *}$
}

\begin{abstract}
Prodigiosin, a secondary metabolite extracted from Serratia marcescens (S. marcescens), could induce apoptosis in various cancer cells, with however low toxicity on normal cells. The red pigment was extracted from a strain S. marcescens NJZT-1 isolated from soil, which had antibacterial activity. Spectral analyses (LC-ESI-MS, UV-VIS spectrophotometry, infrared spectra and HPLC) and TLC indicated the presence of prodigiosin in the extracellular bacterial culture extracts. The red pigment effectively killed the TSC2-null cells, whose mutation resulted in the progressive and systemic disease LAM. Our findings provide interesting evidence and important basis for the development of new therapeutic compounds with high potential effects against TSC2-null cells.
\end{abstract}

Keywords: natural products; prodigiosin; Serratia marcescens (S. marcescens) NJZT-1; anticancer activity; LAMTSC2-null cells.

Practical Application: Serratia marcescens natural products might be applied as a potential anticancer drug for the treatment of LAM patients in clinic.

\section{Introduction}

Prodigiosin is a secondary metabolite alkaloid with unique tripyrrole chemical structure, which is a red pigment isolated from Serratia, Pseudomonas and Streptomyces (Casullo de Araújo et al., 2010; Sam \& Ghoreishi, 2018; Younis et al., 2016). Prodigiosin has a molecular formula of $\mathrm{C}_{20} \mathrm{H}_{25} \mathrm{~N}_{3} \mathrm{O}$ and a molecular weight of 323.44 Da (Hu et al., 2016), with three rings, forming a pyrrolylpyrromethane skeleton with a C-4 methoxy group. Moreover, prodigiosin is moderately soluble in alcohol and ether, and soluble in chloroform, methanol, acetonitrile and DMSO (Hu et al., 2016; Kimata et al., 2017). It has been shown that prodigiosin has a broad range of biological activities, including the antibacterial, antifungal, and antimalarial effects (Hage-Hülsmann et al., 2018; Harris et al., 2004; Lazović et al., 2017; You et al., 2016), as well as the antibiotic, immunosuppressant (Pandey et al., 2007; Yu et al., 2015), antidiabetic, and anti-cancer activities (Genes et al., 2011; Harris et al., 2004; You et al., 2016). Moreover, prodigiosin has also been used as potential dye for food, textile, cosmetics, pharmaceutics and polyolefins (Danevčič et al., 2016; Davient et al., 2018; Dong et al., 2014; Genes et al., 2011; Goncharova et al., 2012).

Nowadays, it is popular to extract the biological products from the plants and microorganism, which have been used in the protection of plants or human beings, due to the natural friendliness (Dai et al., 2017; Dong et al., 2014; Zhao et al., 2017). Prodigiosin is a critical bioactive compound with common applications in the food, pharmaceutical, cosmetic and textile industries. New strains are still being isolated from the surroundings, because different natural products extracted from different strains might have novel bioactivities (Auparakkitanon, 2014; Darshan \& Manonmani, 2016; Dhar Purkayastha et al., 2018; Sturz et al., 1997; Suryawanshi et al., 2015).

S. marcescens is a rod-shaped, Gram negative bacterium belonging to the Enterobacteriaceae family, which is characterized by the ability of producing the red pigment prodigiosin (Ramaprasad et al., 2015). The chromogenic species are usually isolated from the water, soil, plants and/or insects within the environment. Moreover, S. marcescens is a facultative microorganism, and therefore the pigment could be produced under both aerobic and anaerobic conditions (Zabot et al., 2017). Although the role of prodigiosin has not yet been defined in the physiological and biological processes of the strains, it indeed could exert the antifungal, antibacterial and antiprotozoal activities, which might have potential to be used in clinic (Yip et al., 2019). Moreover, both prodigiosin and its synthetic derivatives have potent and specific immunosuppressive activities, with new targets clearly distinct from the other drugs (Woodhams et al., 2018). Furthermore, prodigiosin is effective in inhibiting the tumor cells and inducing the cellular apoptosis, involving a broad range of cancer cell lines (Su et al., 2016; You et al., 2016; Yu et al., 2015). Prodigiosin can inhibit the Wnt/ $\beta$-catenin signaling pathway and exert the anticancer activity in the breast cancer cell (Wang et al., 2016) and reactivate the $\mathrm{p} 53$ family-dependent transcriptional activity in the p53-deficient human colon cancer cells (Prabhu et al., 2016). 
Lymph angioleio myomatosis (LAM) is a rare, progressive and systemic disease that would typically result in the cystic lung destruction, almost exclusively affecting the females, which would be often misdiagnosed as asthma. LAM occurs either in the tuberous sclerosis complex (TSC-LAM) disease, or in the sporadic form (sporadic LAM). In both these two forms, genetic evidence indicates that LAM would be caused by the inactivation or loss-of-function mutations in the TSC1 or TSC2 genes (Liu et al., 2019; Valianou et al., 2019). More and more attention has been paid to finding the resolution and treatment drugs for the disease. Otherwise, the inhibition or apoptosis in the TSC2-null cancer cells triggered by prodigiosin, or the action mechanism underlying the apoptosis triggering activities of the bacterial prodigiosin in human LAM, have not been reported.

In this study, a special Serratia strain was established. The natural product of this strain was subjected to the identification and characterization. Moreover, apoptosis of the TSC2-null cells was also detected to seek for a potential anticancer drug to LAM.

\section{Materials and methods}

\subsection{Microorganism and culture conditions}

A pigmented strain of $S$. marcescens NJZT-1 was isolated from the soil sample from the yard of the Nanjing forestry university, which had the ability to inhibit bacteria. The strain was maintained and cultured on the nutrient agar medium. To obtain an appropriate amount of bacterial biomass and pigment, the strain was transferred into a 1000-mL Erlenmeyer flask, containing $300 \mathrm{~mL}$ Luria Bertani (LB) broth medium, which was incubated at $28{ }^{\circ} \mathrm{C}, \mathrm{pH} 7.2$ for $72 \mathrm{~h}$ at $200 \mathrm{rpm}$. The produced pigment was extracted from the biomass containing S. marcescens, by the centrifugation and methanol digestion. The plates were incubated at $28^{\circ} \mathrm{C}$ for $72 \mathrm{~h}$ until the appearance of red pigmentation.

\subsection{Pigment extraction, purification, and identification}

Pigmented cultures were scraped from the surface of the Petri dishes. The biomass was extracted and collected from the pigmented cultures by the centrifugation at $9,000 \times \mathrm{g}$ for 10 min. Pigment was extracted with the acidified methanol. The crude extract was evaporated by heating in water bath at $60{ }^{\circ} \mathrm{C}$, and the dried pigment was re-dissolved in methanol.

The extracted red pigment was purified by the thin layer chromatography (TLC) in the GF250 silica gel plates. The solvent system used was dichloromethane: Ethyl acetate (1:5). Separated spot of pigment was recovered by eluting from the silica gel with methanol, which was dried by evaporation. The pigment concentration was determined as gram $/ \%$ on the dry weight $(\mathrm{w} / \mathrm{v})$. The dried product was further dissolved in DMSO, and subjected to the UV-visible spectrophotometry in the range of 840-190 nm (Shimadzu UV 1800). Then, the pigment was characterized using the Fourier transform infrared (FTIR) spectrophotometer (BRUKER TENSOR 37, Germany). After drying, the pigment was mixed with the $\mathrm{KBr}$ powder and compressed into the pellet for the FTIR spectroscopy with the frequency range of 4,000-400 $\mathrm{cm}^{-1}$.
The characterization of the purified product was performed with the LC-MS system (Waters Quattro Premier Micromass). The prodigiosin dissolved in methanol was injected into the LC-MS, and MS was performed using the positive ion electrospray ionization, with the following settings: capillary voltage, $3.4 \mathrm{~V}$; cone voltage, $30 \mathrm{~V}$; and source temperature, $100^{\circ} \mathrm{C}$.

\subsection{Cell lines and cell culture}

The TSC2-null cancer cells were kindly donated by Dr. John Blenis (Weill Cornell Medical College, New York, NY, USA). The cells were cultured in the Dulbecco's modified Eagle's medium (Hyclone; GE Healthcare Life Sciences, Logan, UT, USA), containing $10 \%$ fetal bovine serum (FBS; Biological Industries, Bat Haemek, Israel), supplemented with $1 \%$ penicillin/streptomycin (Sigma-Aldrich, Merck KGaA, Darmstadt, Germany), in a $37^{\circ} \mathrm{C}, 5 \% \mathrm{CO}_{2}$ incubator.

\subsection{Cell counting kit 8 (CCK8) assay}

Cell proliferation and cytotoxicity was measured with the CCK8 assay. Cells in the logarithmic growth phase were collected and inoculated onto the 96 -well plate, at the density of $1 \times 10^{3} /$ well, which were cultured in a $37^{\circ} \mathrm{C}, 5 \% \mathrm{CO}_{2}$ incubator. After $24 \mathrm{~h}$, $100 \mu \mathrm{L}$ complete medium containing prodigiosin (at different dosages) was added into each well to incubate the cells for $48 \mathrm{~h}$ and $72 \mathrm{~h}$, respectively. Then, totally $10 \mu \mathrm{L}$ CCK- 8 solution was added into each well, followed by incubation in dark at $37^{\circ} \mathrm{C}$ for $2 \mathrm{~h}$. The optical density at $450 \mathrm{~nm}$ was read with a microplate reader (Bio-Rad Laboratories).

\subsection{Flow cytometry}

Cellular apoptosis and necrosis were detected by flow cytometry with the apoptosis kit (Harlingen; BD Biosciences, Franklin Lakes, NJ, USA). After the treatment of prodigiosin at different dosages for $48 \mathrm{~h}$, the cell culture supernatant was discarded, and the cells were centrifuged at $2000 \mathrm{rpm}$ for $5 \mathrm{~min}$. After washing and centrifugation, the cells were re-suspended in $500 \mu \mathrm{L} 1 \times$ binding buffer. Then the cells suspension was treated with $5 \mu \mathrm{L}$ Annexin $\mathrm{V}$ and propidium iodide (PI) in turn, followed by incubation in dark at room temperature for $15 \mathrm{~min}$. The fluorescence was then determined using a FACSCalibur flow cytometer, and the percentage of apoptotic cells were counted and calculated.

\section{Results}

\subsection{Strain isolation and product extraction, charaterization and identification}

The S. marcescens NJZT-1 strain was isolated, with the temperature-stability according to the previous study, and the red pigment could be synthesized at $37^{\circ} \mathrm{C}$. Moreover, the strain could inhibit bacteria, including the fusarium and bacillus cereus mycoides. Our results showed that the colony of S. marcescens NJZT-1 was different with other S. marcescens strains, due to the red exudate around the colony (Figure 1A). It has been known that most metabolites of the $S$. marcescens 
are fat-soluble and insoluble in water, including prodigiosin (Hu et al., 2016; You et al., 2016). Our results showed that the red exudate surrounding the colony in the tablet was soluble in water, which might be prodigiosin. This strain might produce and synthesize the red pigment prodigiosin.

The cell mass was cultured in the Luria Bertani (LB) broth medium and collected through centrifugation. The obtained crude prodigiosin extract was first purified by the thin layer chromatography (TLC). The TLC was performed for the isolated pigment on standard silica gel Gf254 plates, with the dichloromethane:ethyl acetate (1:5) as the solvent. Our results showed that the Rf value of the sample and standard was 0.6 (Figure 2). Moreover, the pigment from the TLC had a strong absorption band with the absorption maximum at $535 \mathrm{~nm}$ (Figure 2).

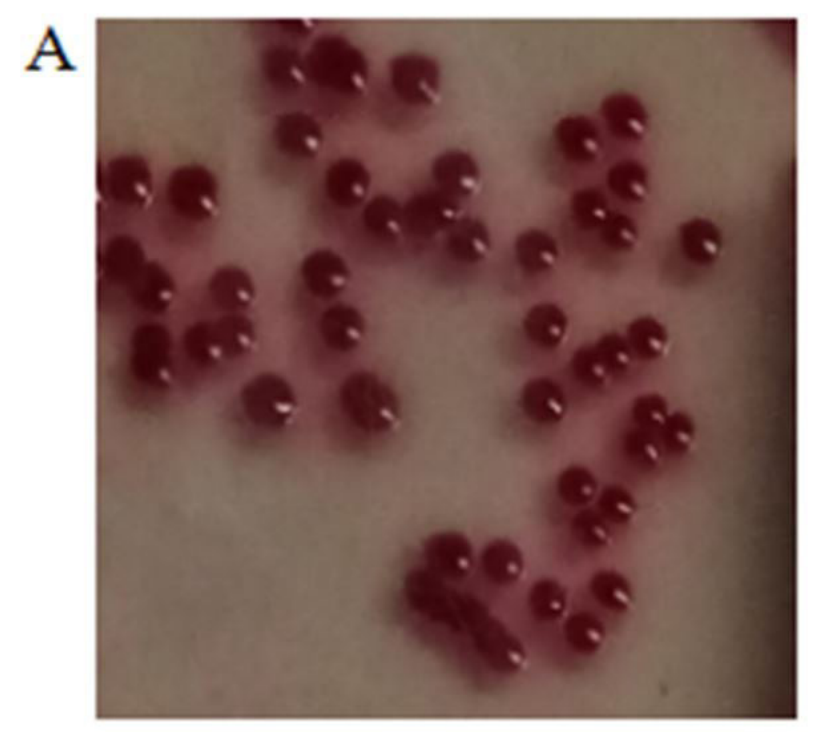

In addition, the FTIR was also performed for the product characterization. As shown in Figure 3, our results showed that the red pigment from Serratia had strong and broad absorptions at $3,325 \mathrm{~cm}^{-1}$ (N-H stretch), 2,941 $\mathrm{cm}^{-1}$ (C-H and $\mathrm{C}=\mathrm{O}$ stretches). A previous study has shown that prodigiosin exhibits similar absorptions in $\mathrm{CHCl} 3$ at $1,660 \mathrm{~cm}^{-1}$ and $1,602 \mathrm{~cm}^{-1}$ (Lazović et al., 2017). Moreover, the N-H group and phenyl rings were evident at the fingerprint region, which was characterized by the weak intensity at $1 \mathrm{~cm}^{-1}$ (aromatic $\mathrm{C}=0$ ). Furthermore, the absorptions at $1,022 \mathrm{~cm}^{-1}$ and $1,114 \mathrm{~cm}^{-1}$ showed the $\mathrm{C}-\mathrm{N}$ bend (amines) and C-O (carboxylic) stretch, while the $846 \mathrm{~cm}^{-1}$ and $737 \mathrm{~cm}^{-1}$ indicated the $\mathrm{C}-\mathrm{H}$ phenyl ring bend, and the weak absorption at $1,461 \mathrm{~cm}^{-1}$ indicated the bending of C-H.

The red pigment extracted from strain NJZT-1 were next determined by the high performance liquid chromatography

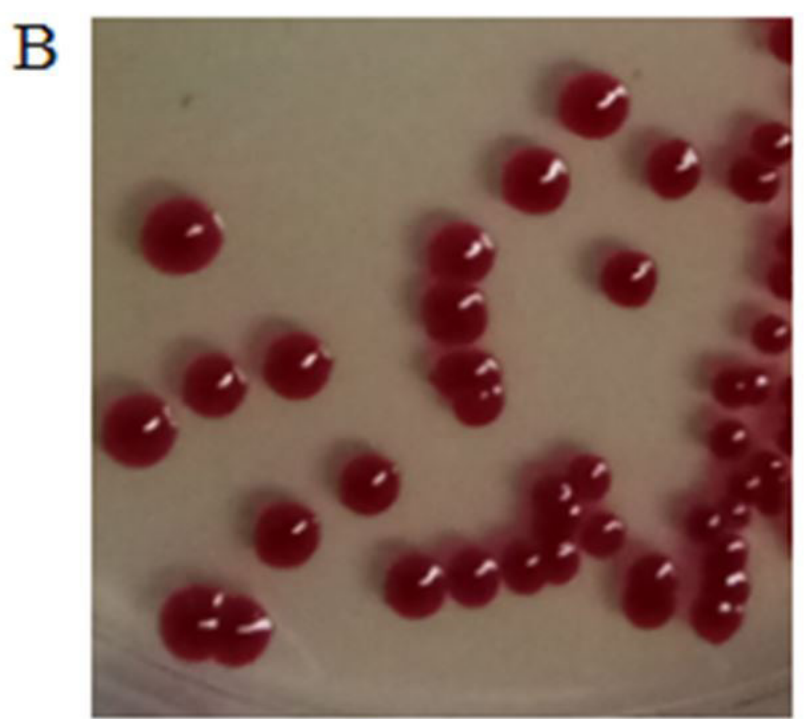

Figure 1. Serratia marcescens (S. marcescens) growing on the LB tablet (A: S. marcescens NJZT-1in our study B: S. marcescens in common).
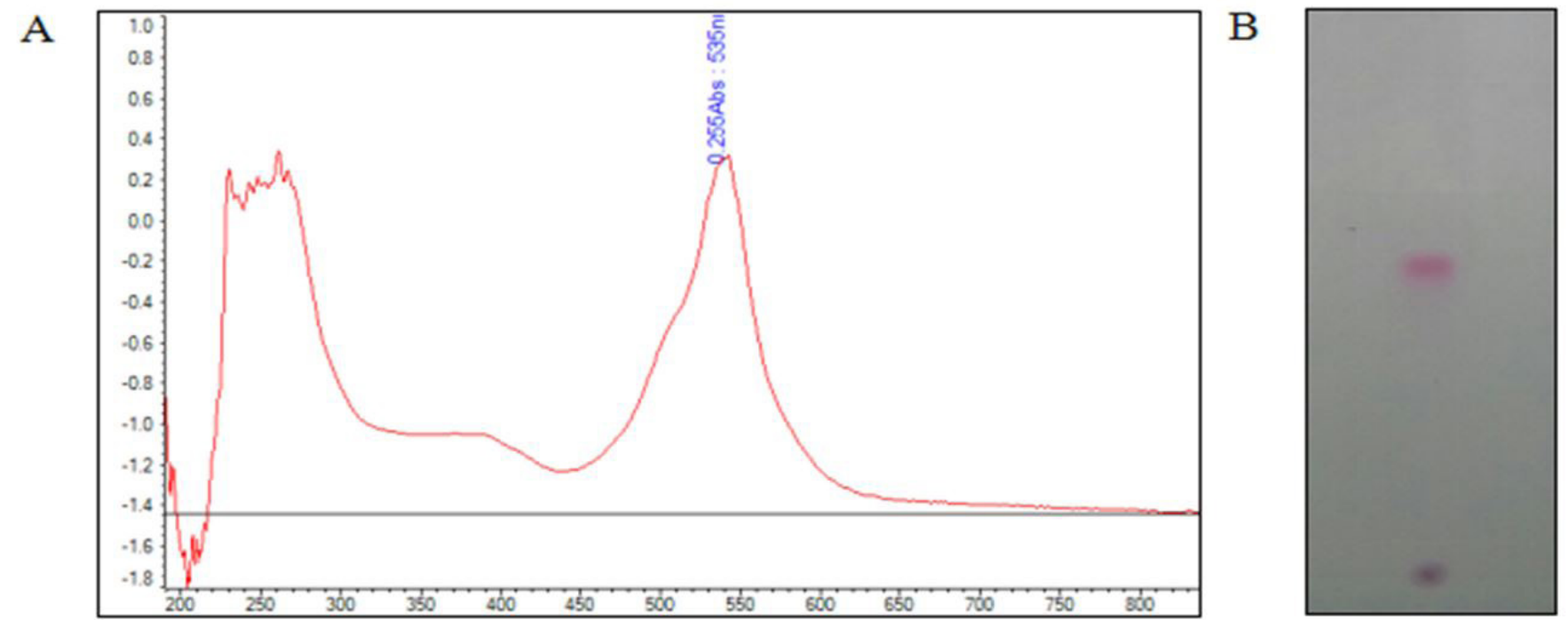

Figure 2. Characterization of the red pigment extract from S.marcescens NJZT-1. (A) Ultraviolet absorption spectrum graph; (B) The thin cell chromatography (B). 
coupled with mass spectrometry (HPLC-MS). Our results from the HPLC analysis showed that, the major product was eluted at $14.323 \mathrm{~min}$ (Figure 4A), similar to the pervious investigation of prodigiosin (Li et al., 2016). Moreover, as shown in Figure 4B, there was a molecular ion peak $\mathrm{M}+\mathrm{H}$ of prodigiosin at $\mathrm{m} / \mathrm{z}$ 324 , which corresponded to the molecular weight of prodigiosin $\left(\mathrm{C}_{20} \mathrm{H}_{25} \mathrm{~N}_{3} \mathrm{O}, 323 \mathrm{kD}\right)$.

\subsection{Anticancer effects of the extracted prodigiosin}

Our precious work has shown the antimicrobial activities of the red pigment extracted from the $S$. marcescens NJZT-1.
Moreover, prodigiosin has been well accepted for its anticancer property and apoptosis-triggering effects of malignant cancer cells. Herein, the anticancer effects of the extracted prodigiosin were investigated with the TSC2-null cells (a typical in vitro model for LAM). As shown in Figure 5, our results showed that the extracted prodigiosin effectively inhibited the growth of the TSC2-null cells, in a dose- and time-dependent manner.

To detect whether the extracted prodigiosin affected the proliferation of TSC2-null cells, the CCK8 assay was performed. Our results showed that the prodigiosin significantly inhibited the vitality and proliferation of TSC2-null cells. Moreover, there

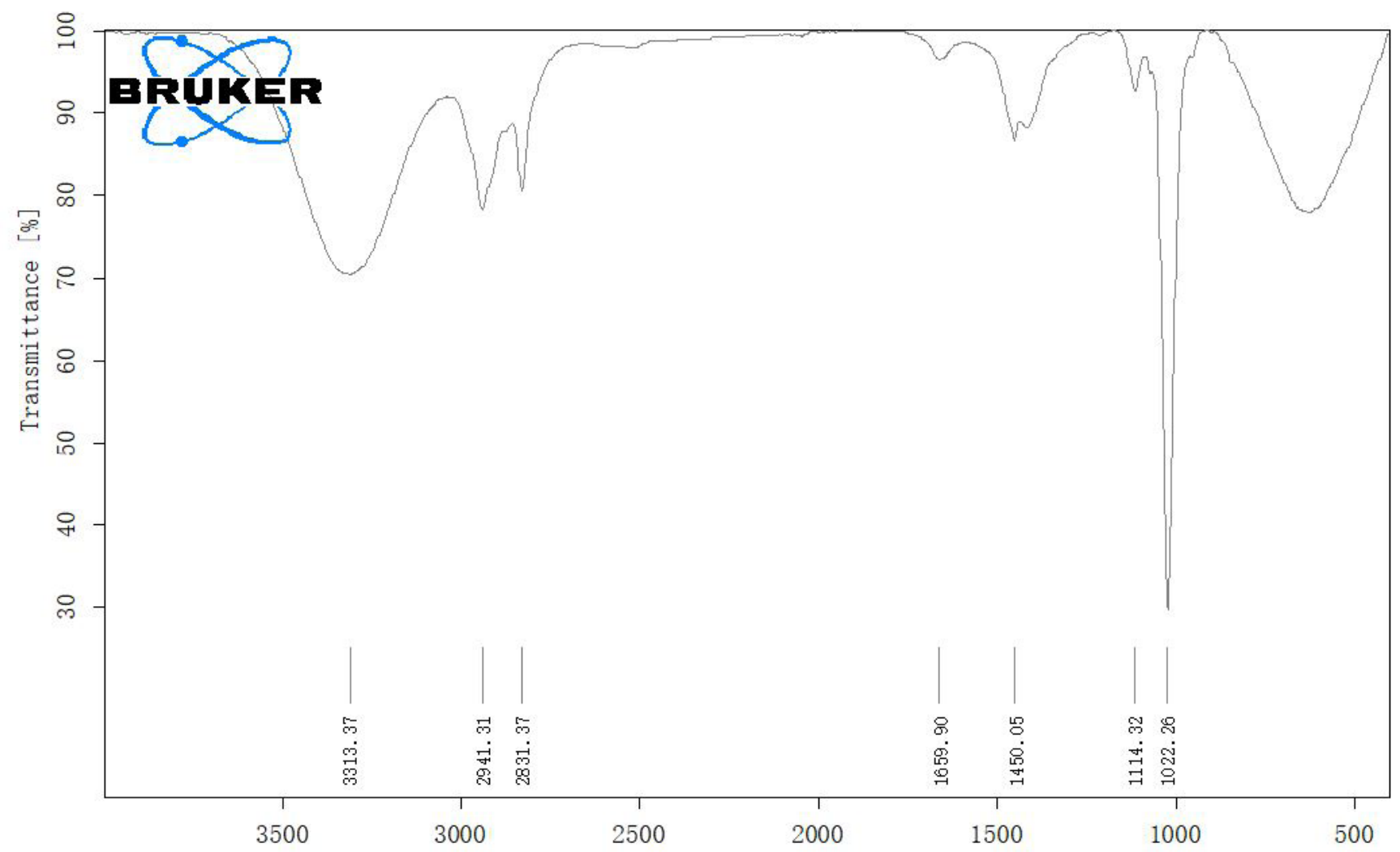

Figure 3. Infrared spectrum for the red pigment.
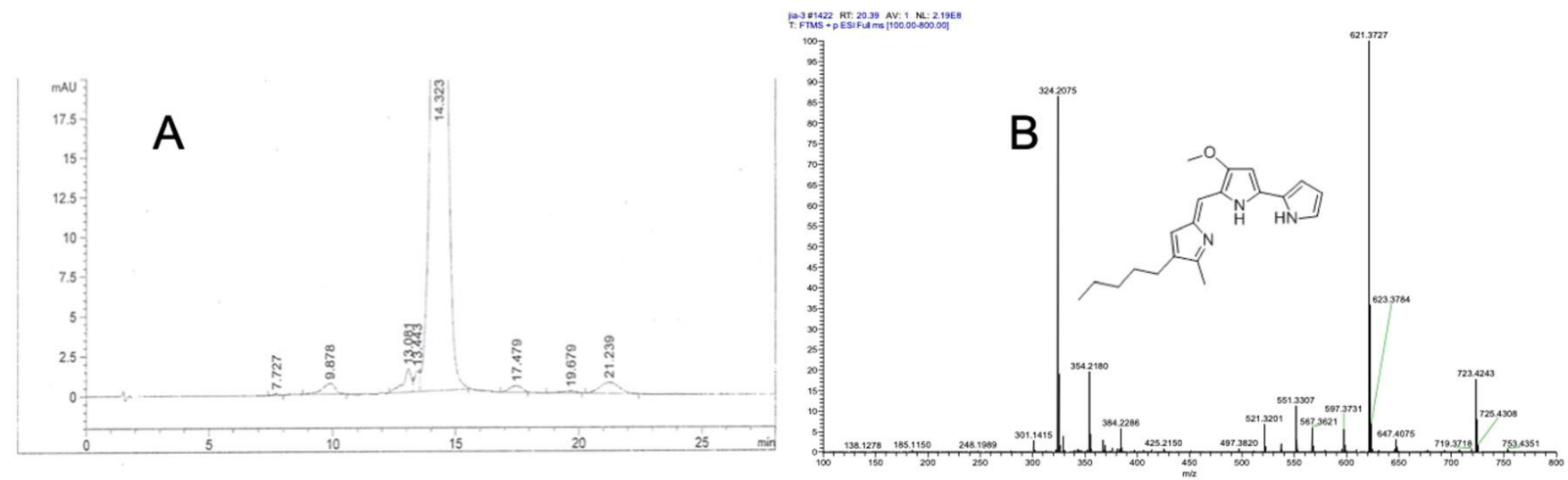

Figure 4. Characterization of the red pigment. (A) HPLC; (B) Mass spectrum. 
was positive correlation between the inhibiting rate and the concentration, except for P1/8 (Figure 6) .

\subsection{Apoptosis-triggering effects of the extracted prodigiosin}

To further explore how the prodigiosin killed the cells effectively, the TSC2-null cells treated with various concentration of the extracted prodigiosin were subjected to the apoptosis detection with flow cytometry. As shown in Figure 7, our results showed that, the prodigiosin significantly triggered the apoptotic processes of the TSC2-null cells, in a dose-dependent manner.
These results suggest that the bacterial prodigiosin could induce apoptosis in the cancer cells, even necrosis.

\section{Discussion}

The red pigment was isolated from the S.marcescens NJZT-1 strain, which was isolated from soil, with the temperature-stability. S. marcescens is the main strain producing prodigiosin, as a secondary metabolite and natural product. The temperature is the key factor for the prodigiosin production. It has been shown that, S.marcescens can produce this kind of pigment at
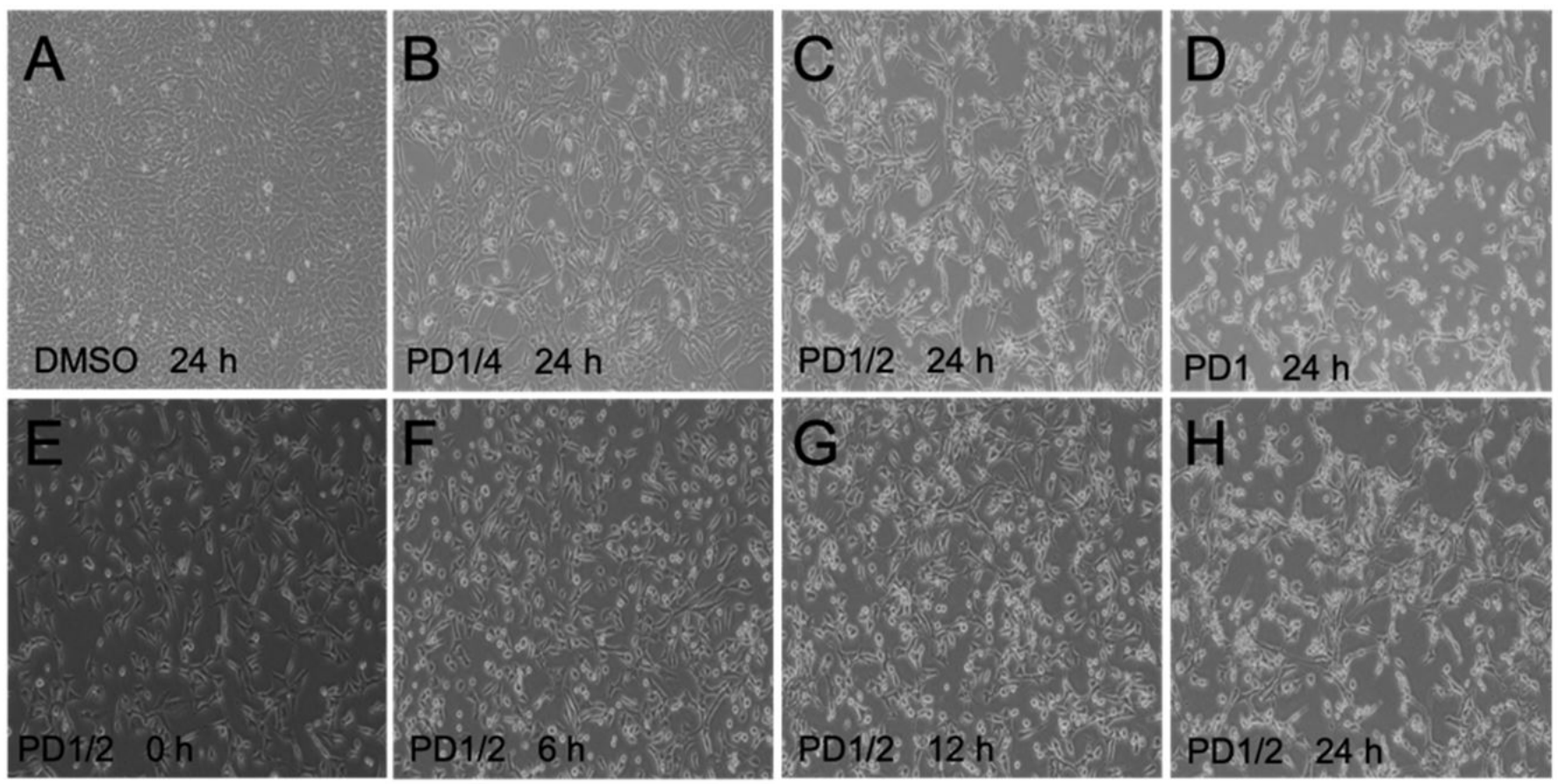

Figure 5. Prodigiosin killed TSC2-null (Tuberous sclerosis complex) cells in a dose-dependent and time-dependent manner. (A) The TSC2-null cells kept in DMSO (Dimethyl sulfoxide) for $24 \mathrm{~h}$ were used as control; (B-D) Prodigiosin was applied to treat the TSC2-null cells, at indicated concentrations, for $24 \mathrm{~h}$; (E-H) The cells treated with $1 / 2$ prodigiosin, for different durations, were also compared. TSC (Tuberous sclerosis complex), DMSO (Dimethyl sulfoxide).

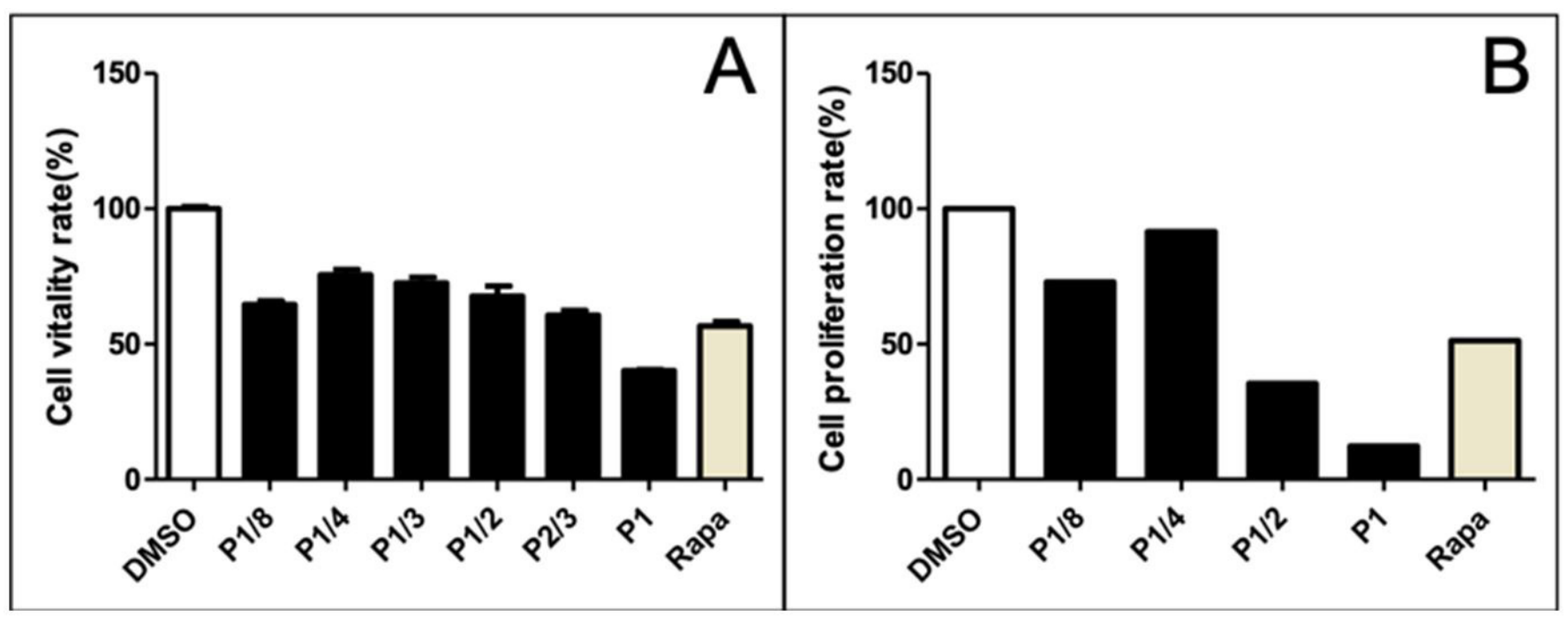

Figure 6. Prodigiosin inhibited the vitality (A) and proliferation (B) of TSC2-null cells. DMSO (Dimethyl sulfoxide). 

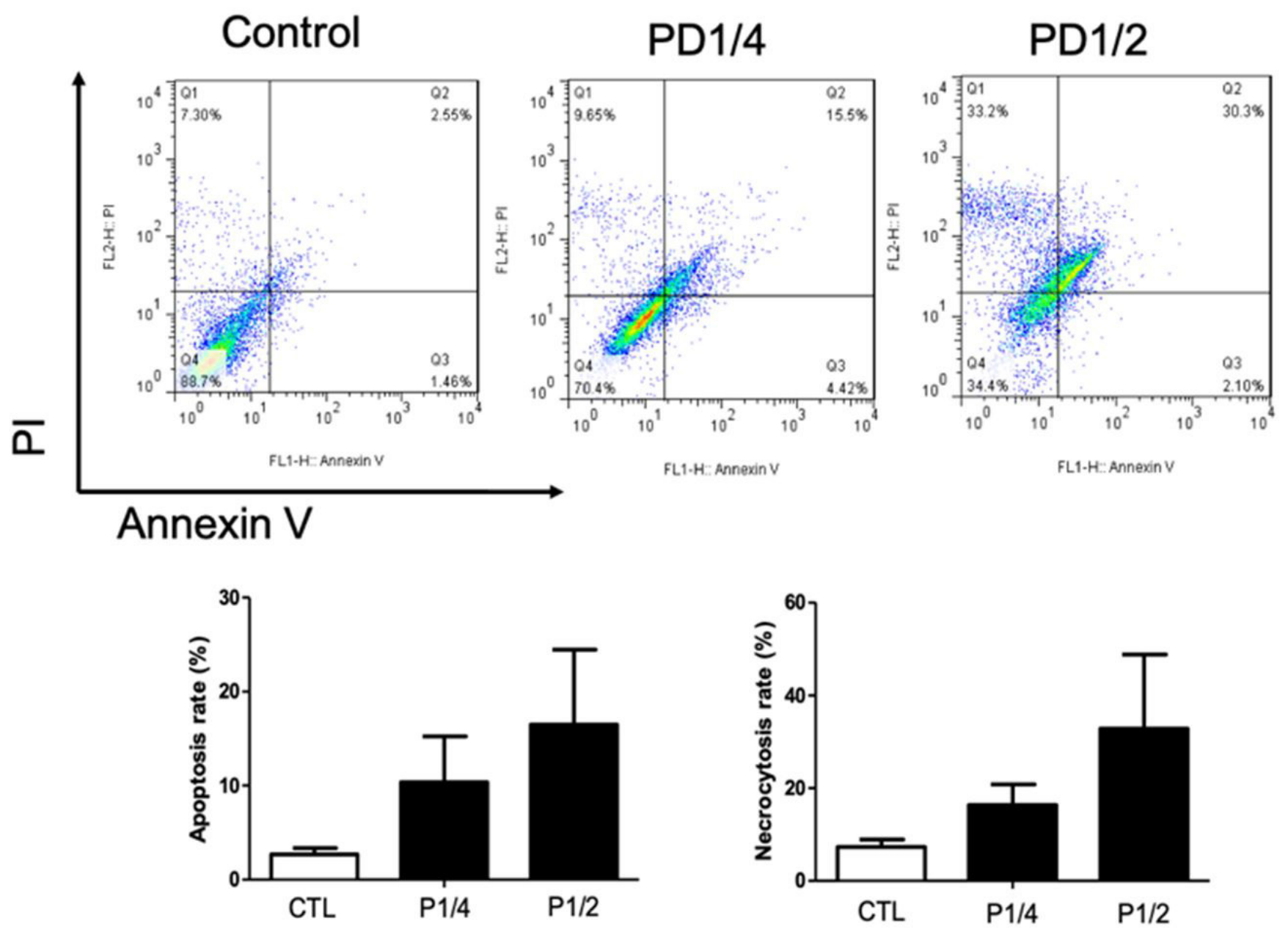

Figure 7. Apoptosis triggering activities of prodigiosin from S. marcescens NJZT-1 in vitro. The TSC2-null cells were subjected to the dual staining of Annex V and PI, and the fluorescence was detected with the flow cytometry. The Annex V+/PI-cells indicated the cells undergoing early apotosis. CTL: control.

about $25{ }^{\circ} \mathrm{C}$, which however could not produce the pigments at elevated temperatures, especially till $37^{\circ} \mathrm{C}$ (Tanikawa et al., 2006). The NJZT-1 strain in this study was not so sensitive to the temperature. It has a good ability to produce pigments in a wide ranged of temperature, i.e., from $20^{\circ} \mathrm{C}$ to $35^{\circ} \mathrm{C}$, even at $37^{\circ} \mathrm{C}$.

Our results showed that, a red halo appeared on the plate, which did not exist in other S. marcescens strains. As is known to all, the red pigment produced by $S$. marcescens is the prodigiosin, which is considered as a fat-soluble substance (Williamson et al., 2006). But the pigment produced by the S. marcescens NJZT-1 could penetrate into the plate, indicating that it had good water solubility. Therefore, it is likely that there are some structural differences. However, the structure of this red pigment was not significantly different from the prodigiosin according to the spectral analyses (LC-ESI-MS, UV-VIS spectrophotometry, infrared spectra and HPLC). It would be possible that the red pigment produced by the bacterium would contain prodigiosin and/or its analogues (the soluble analogues might account for a small proportion), resulting the final product that was identified as prodigiosin.

The effects of the extracted product on the vitality and proliferation of the TSC2-null cells were also investigated. In these cells, the gene mutations result in the progressive and systemic disease of LAM. LAM is a rarely seen progressive mesenchymal neoplasm mainly affecting childbearing-age women (Baldi et al., 2014; McCormack, 2008; Kelly \& Moss, 2001; Peron \& Northrup, 2018). The LAM cases are sometime difficult to diagnose because the disease symptoms are similar to other lung diseases (such as asthma, emphysema, and bronchitis). Up to now, there is still no effective therapies that could cure LAM, while only the lung transplantation can save the life of LAM patients. During 2000-2006, some studies have found that the somatic mutation of TSC2 gene in the LAM patients would cause abnormal proliferation of LAM cells (Carsillo et al., 2000; Muzykewicz et al., 2009). In this study, our results showed that the extracted prodigiosin effectively killed the TSC2-null cells by inducing the cellular apoptosis and necrosis. These findings might provide an important and interesting basis for the development of the new therapeutic compound with high potential against the TSC2-null cells.

In this study, our results showed that the prodigiosin was a potential medical compound for inhibiting the growth of TSC2-null cells. However, further in-depth studies are still need to address the specific anticancer mechanism of $S$. marcescens 
NJZT-1 prodigiosin. Because the mTOR pathway has been shown to be abnormally activated in the TSC2-null cells, the $\mathrm{p}$-S6K and p-S6 could be chosen as the targets to investigate whether the prodigiosin inhibits the proliferation of TSC2-null cells through the mTOR pathway (Li et al., 2016). Besides, the elevated expression of cleaved-PARP1 could be induced by prodigiosin, indicating that prodigiosin can induce the TSC2-null cell apoptosis, which also deserves further analysis in the future.

\section{Acknowledgements}

This work was supported by the Priority Academic Program Development of Jiangsu Higher Education Institutions (PAPD), the National Natural Science Foundation of China (No. 31100448), the Research Fund for the Doctoral Program of Higher Education of China (No. 20113204120004), and the Postdoctoral Foundation of Jiangsu Province.

\section{References}

Auparakkitanon, S. (2014). Discovery and development of antiplasmodial compounds in thailand during the 21 st century. The Southeast Asian Journal of Tropical Medicine and Public Health, 45(4), 761-782. PMid:25427344.

Baldi, B. G., Freitas, C. S., Araujo, M. S., Dias, O. M., Pereira, D. A., Pimenta, S. P., Kairalla, R. A., \& Carvalho, C. R. (2014). Clinical course and characterisation of lymphangioleiomyomatosis in a Brazilian reference centre. Sarcoidosis, Vasculitis, and Diffuse Lung Diseases, 31(2), 129-135. PMid:25078640.

Carsillo, T., Astrinidis, A., \& Henske, E. P. (2000). Mutations in the tuberous sclerosis complex gene TSC2 are a cause of sporadic pulmonary lymphangioleiomyomatosis. Proceedings of the National Academy of Sciences of the United States of America, 97(11), 60856090. http://dx.doi.org/10.1073/pnas.97.11.6085. PMid:10823953.

Casullo de Araújo, H. W., Fukushima, K., \& Takaki, G. M. C. (2010). Prodigiosin production by Serratia marcescens UCP 1549 using renewable-resources as a low cost substrate. Molecules, 15(10), 69316940. http://dx.doi.org/10.3390/molecules15106931. PMid:20938403.

Dai, T., Xu, Z., Zhou, X., Li, B., \& Mao, S. (2017). The inhibitory effect of the plant alkaloid camptothecin on the rice sheath blight pathogen Rhizoctonia solani. International Journal of Agriculture and Biology, 19(3), 558-562. http://dx.doi.org/10.17957/IJAB/15.0335.

Danevčič, T., Borić Vezjak, M., Tabor, M., Zorec, M., \& Stopar, D. (2016). Prodigiosin induces autolysins in actively grown bacillus subtilis cells. Frontiers in Microbiology, 7, 27. http://dx.doi.org/10.3389/ fmicb.2016.00027. PMid:26858704.

Darshan, N., \& Manonmani, H. K. (2016). Prodigiosin inhibits motility and activates bacterial cell death revealing molecular biomarkers of programmed cell death. AMB Express, 6(1), 50. http://dx.doi. org/10.1186/s13568-016-0222-z. PMid:27460563.

Davient, B., Ng, J. P. Z., Xiao, Q., Li, L., \& Yang, L. (2018). Comparative transcriptomics unravels prodigiosin's potential Cancer-Specific activity between human small airway epithelial cells and lung adenocarcinoma cells. Frontiers in Oncology, 8(573), 573. http:// dx.doi.org/10.3389/fonc.2018.00573. PMid:30568916.

Dhar Purkayastha, G., Mangar, P., Saha, A., \& Saha, D. (2018). Evaluation of the biocontrol efficacy of a Serratia marcescens strain indigenous to tea rhizosphere for the management of root rot disease in tea. PLoS One, 13(2), e1917612. http://dx.doi.org/10.1371/journal. pone.0191761. PMid:29466418.
Dong, R., Gu, L., Guo, C., Xun, F., \& Liu, J. (2014). Effect of PGPR Serratia marcescens $\mathrm{BC}-3$ and AMF Glomus intraradices on phytoremediation of petroleum contaminated soil. Ecotoxicology, 23(4), 674-680. http:// dx.doi.org/10.1007/s10646-014-1200-3. PMid:24482052.

Genes, C., Baquero, E., Echeverri, F., Maya, J. D., \& Triana, O. (2011). Mitochondrial dysfunction in Trypanosoma cruzi: the role of Serratia marcescens prodigiosin in the alternative treatment of Chagas disease. Parasites \& Vectors, 4(1), 66. http://dx.doi.org/10.1186/1756-33054-66. PMid:21548954.

Goncharova, E. A., Goncharov, D. A., Fehrenbach, M., Khavin, I., Ducka, B., Hino, O., Colby, T. V., Merrilees, M. J., Haczku, A., Albelda, S. M., \& Krymskaya, V. P. (2012). Prevention of alveolar destruction and airspace enlargement in a mouse model of pulmonary lymphangioleiomyomatosis (LAM). Science Translational Medicine, 4(154), 154r-134154r. http:// dx.doi.org/10.1126/scitranslmed.3003840. PMid:23035046.

Hage-Hülsmann, J., Grünberger, A., Thies, S., Santiago-Schübel, B., Klein, A. S., Pietruszka, J., Binder, D., Hilgers, F., Domröse, A., Drepper, T., Kohlheyer, D., Jaeger, K.-E., \& Loeschcke, A. (2018). Natural biocide cocktails: Combinatorial antibiotic effects of prodigiosin and biosurfactants. PLoS One, 13, e0200940. http://dx.doi.org/10.1371/ journal.pone.0200940. PMid:30024935.

Harris, A., Williamson, N. R., Slater, H., Cox, A., Abbasi, S., Foulds, I., Simonsen, H. T., Leeper, F. J., \& Salmond, G. (2004). The Serratia gene cluster encoding biosynthesis of the red antibiotic, prodigiosin, shows species-and strain-dependent genome context variation. Microbiology, 150(11), 3547-3560. http://dx.doi.org/10.1099/ mic.0.27222-0. PMid:15528645.

Hu, D. X., Withall, D. M., Challis, G. L., \& Thomson, R. J. (2016). Structure, chemical synthesis, and biosynthesis of prodiginine natural products. Chemical Reviews, 116(14), 7818-7853. http:// dx.doi.org/10.1021/acs.chemrev.6b00024. PMid:27314508.

Kelly, J. M. J., \& Moss, J. (2001). Lymphangioleiomyomatosis. The American Journal of the Medical Sciences, 321(1), 17-25. http:// dx.doi.org/10.1097/00000441-200101000-00004. PMid:11202475.

Kimata, S., Izawa, M., Kawasaki, T., \& Hayakawa, Y. (2017). Identification of a prodigiosin cyclization gene in the roseophilin producer and production of a new cyclized prodigiosin in a heterologous host. The Journal of Antibiotics, 70(2), 196-199. http://dx.doi.org/10.1038/ ja.2016.94. PMid:27460763.

Lazović, S., Leskovac, A., Petrovic, S., Senerovic, L., Krivokapic, N., Mitrovic, T., Bozovic, N., Vasic, V., \& Nikodinovic-Runic, J. (2017). Biological effects of bacterial pigment undecylprodigiosin on human blood cells treated with atmospheric gas plasma in vitro. Experimental and Toxicologic Pathology, 69(1), 55-62. http://dx.doi.org/10.1016/j. etp.2016.11.003. PMid:27843060.

Li, H., Jin, F., Jiang, K., Ji, S., Wang, L., Ni, Z., Chen, X., Hu, Z., Zhang, H., Liu, Y., Qin, Y., \& Zha, X. (2016). MTORC1-mediated downregulation of COX2 restrains tumor growth caused by TSC2 deficiency. Oncotarget, 7(19), 28435-28447. http://dx.doi.org/10.18632/ oncotarget.8633. PMid:27078846.

Liu, J., Yuan, J., Feng, T., Zhao, Y., Sun, Q., Chen, J., Chen, J., Jin, M., \& Xue, B. (2019). MiR124 targets retinoid X receptor alpha to reduce growth of TSC2deficient lymphangioleiomyomatosis. Oncology Reports, 41(2), 1342-1350. PMid:30535437.

McCormack, F.X. (2008). Lymphangioleiomyomatosis: a clinical update. Chest, 133(2), 507-516. http://dx.doi.org/10.1378/chest.07-0898. PMid:18252917.

Muzykewicz, D. A., Sharma, A., Muse, V., Numis, A. L., Rajagopal, J., \& Thiele, E. A. (2009). TSC1 and TSC2 mutations in patients with lymphangioleiomyomatosis and tuberous sclerosis complex. Journal of Medical Genetics, 46(7), 465-468. http://dx.doi.org/10.1136/ jmg.2008.065342. PMid:19419980. 
Pandey, R., Chander, R., \& Sainis, K. B. (2007). Prodigiosins: A novel family of immunosuppressants with anti-cancer activity. Indian Journal of Biochemistry \& Biophysics, 44(5), 295-302. PMid:18341204.

Peron, A., \& Northrup, H. (2018). Tuberous sclerosis complex. American Journal of Medical Genetics. Part C, Seminars in Medical Genetics, 178(3), 274-277. http://dx.doi.org/10.1002/ajmg.c.31657. PMid:30325570.

Prabhu, V. V., Hong, B., Allen, J. E., Zhang, S., Lulla, A. R., Dicker, D. T., \& El-Deiry, W. S. (2016). Small-molecule prodigiosin restores p53 tumor suppressor activity in chemoresistant colorectal cancer stem cells via c-Jun-Mediated DeltaNp73 inhibition and p73 activation. Cancer Research, 76(7), 1989-1999. http://dx.doi.org/10.1158/00085472.CAN-14-2430. PMid:26759239.

Ramaprasad, E. V. V., Bharti, D., Sasikala, C., \& Ramana, C. V. (2015). Zooshikella marina sp nov a cycloprodigiosin- and prodigiosin-producing marine bacterium isolated from beach sand. International Journal of Systematic and Evolutionary Microbiology, 65(12), 4669-4673. http://dx.doi.org/10.1099/ ijsem.0.000630. PMid:26409875.

Sam, M. R., \& Ghoreishi, S. (2018). Prodigiosin produced by Serratia marcescens inhibits expression of MMP-9 and survivin and promotes caspase- 3 activation with induction of apoptosis in acute lymphoblastic leukaemia cells. Journal of Applied Microbiology, 125(4), 1017-1029. http://dx.doi.org/10.1111/jam.13949. PMid:29896797.

Sturz, A. V., Christie, B. R., Matheson, B. G., \& Nowak, J. (1997). Biodiversity of endophytic bacteria which colonize red clover nodules, roots, stems and foliage and their influence on host growth. Biology and Fertility of Soils, 25(1), 13-19. http://dx.doi.org/10.1007/ s003740050273.

Su, C., Xiang, Z., Liu, Y., Zhao, X., Sun, Y., Li, Z., Li, L., Chang, F., Chen, T., Wen, X., Zhou, Y., \& Zhao, F. (2016). Analysis of the genomic sequences and metabolites of Serratia surfactantfaciens sp nov YD25(T) that simultaneously produces prodigiosin and serrawettin W2. BMC Genomics, 17(1), 865. http://dx.doi.org/10.1186/s12864016-3171-7. PMid:27809759.

Suryawanshi, R. K., Patil, C. D., Borase, H. P., Narkhede, C. P., Salunke, B. K., \& Patil, S. V. (2015). Mosquito larvicidal and pupaecidal potential of prodigiosin from Serratia marcescens and understanding its mechanism of action. Pesticide Biochemistry and Physiology, 123, 49-55. http://dx.doi.org/10.1016/j.pestbp.2015.01.018. PMid:26267052.

Tanikawa, T., Nakagawa, Y., \& Matsuyama, T. (2006). Transcriptional downregulator hexS controlling prodigiosin and serrawettin W1 biosynthesis in Serratia marcescens. Microbiology and Immunology, 50(8), 587-596. http://dx.doi.org/10.1111/j.1348-0421.2006.tb03833.x. PMid:16924143.
Valianou, M., Filippidou, N., Johnson, D. L., Vogel, P., Zhang, E. Y., Liu, X., Lu, Y., Yu, J. J., Bissler, J. J., \& Astrinidis, A. (2019). Rapalog resistance is associated with mesenchymal-type changes in Tsc2null cells. Scientific Reports, 9(1), 3015. http://dx.doi.org/10.1038/ s41598-019-39418-5. PMid:30816188.

Wang, Z., Li, B., Zhou, L., Yu, S., Su, Z., Song, J., Sun, Q., Sha, O., Wang, X., Jiang, W., Willert, K., Wei, L., Carson, D. A., \& Lu, D. (2016). Prodigiosin inhibits Wnt/beta-catenin signaling and exerts anticancer activity in breast cancer cells. Proceedings of the National Academy of Sciences of the United States of America, 113(46), 13150-13155. http://dx.doi.org/10.1073/pnas.1616336113. PMid:27799526.

Williamson, N. R., Fineran, P. C., Leeper, F. J., \& Salmond, G. P. (2006). The biosynthesis and regulation of bacterial prodiginines. Nature Reviews. Microbiology, 4(12), 887-899. http://dx.doi.org/10.1038/ nrmicro1531. PMid:17109029.

Woodhams, D. C., LaBumbard, B. C., Barnhart, K. L., Becker, M. H., Bletz, M. C., Escobar, L. A., Flechas, S. V., Forman, M. E., Iannetta, A. A., Joyce, M. D., Rabemananjara, F., Gratwicke, B., Vences, M., \& Minbiole, K. P. C. (2018). Prodigiosin, violacein, and volatile organic compounds produced by widespread cutaneous bacteria of amphibians can inhibit two batrachochytrium fungal pathogens. Microbial Ecology, 75(4), 10491062. http://dx.doi.org/10.1007/s00248-017-1095-7. PMid:29119317.

Yip, C., Yarkoni, O., Ajioka, J., Wan, K., \& Nathan, S. (2019). Recent advancements in high-level synthesis of the promising clinical drug, prodigiosin. Applied Microbiology and Biotechnology, 103(4), 16671680. http://dx.doi.org/10.1007/s00253-018-09611-z. PMid:30637495.

You, Z., Wang, Y., Sun, S., \& Liu, X. (2016). Progress in microbial production of prodigiosin. Sheng Wu Gong Cheng Xue Bao, 32(10), 1332-1347. PMid:29027444.

Younis, K. M., Usup, G., \& Ahmad, A. (2016). Secondary metabolites produced by marine streptomyces as antibiofilm and quorum-sensing inhibitor of uropathogen Proteus mirabilis. Environmental Science and Pollution Research International, 23(5), 4756-4767. http://dx.doi. org/10.1007/s11356-015-5687-9. PMid:26538254.

Yu, C., Ou, J., Wang, M., Jialielihan, N., \& Liu, Y. (2015). Elevated survivin mediated multidrug resistance and reduced apoptosis in breast cancer stem cells. Journal of the Balkan Union of Oncology, 20(5), 1287-1294. PMid:26537077.

Zabot, G. P., Carvalhal, G. F., Marroni, N. P., Licks, F., Hartmann, R. M., Da Silva, V. D., \& Fillmann, H. S. (2017). Glutamine prevents oxidative stress in a model of portal hypertension. World Journal of Gastroenterology, 23(25), 4529-4537. http://dx.doi.org/10.3748/ wjg.v23.i25.4529. PMid:28740341.

Zhao, Y., Xu, L., \& Hua, Y. (2017). Effects of Dendrobium officinale polysaccharide on adipogenic differentiation of rat bone marrow mesenchymal stem cells. Food Science and Technology, 37(2), 303307. http://dx.doi.org/10.1590/1678-457x.22716. 